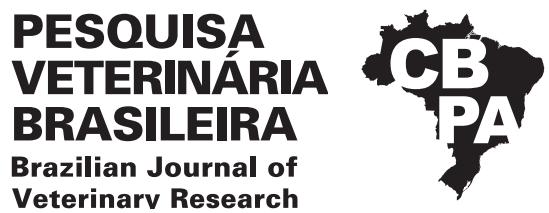

Pesq. Vet. Bras. 41:e06848, 2021 DOI: $10.1590 / 1678-5150-P V B-6848$

Original Article Veterinarv Research

ISSN 0100-736X (Print)

ISSN 1678-5150 (Online)

\title{
Poisoning by Megathyrsus maximus (Sin. Panicum maximum) cv. Colonião in horses in the state of Rio de Janeiro ${ }^{1}$
}

\author{
Ticiana N. França ${ }^{2 *}$ (D), Stephni M. Carletti ${ }^{3}$, Juliana F. Rocha² (D), \\ Bartolomeu B.N. Santos ${ }^{2}$, Mariana C. Oliveira² ${ }^{2}$ Daniel G. Ubiali ${ }^{2}$ (D), \\ Pedro Malafaia ${ }^{4}$ and Paulo Vargas Peixoto ${ }^{5}$
}

\begin{abstract}
França T.N., Carletti S.M., Rocha J.F., Santos B.B.N., Oliveira M.C., Ubiali D.G., Malafaia P. \& Peixoto P.V. 2021. Poisoning by Megathyrsus maximus (Sin. Panicum maximum) cv. Colonião in horses in the state of Rio de Janeiro. Pesquisa Veterinária Brasileira 41:e06848, 2021. Setor de Anatomia Patológica Veterinária, Departamento de Epidemiologia e Saúde Pública, Universidade Federal Rural do Rio de Janeiro, BR-465 Km 7, Seropédica, RJ 23890-000, Brazil. E-mail: ticianafranca19@gmail.com

Colic outbreaks in horses have been associated with the grazing of several Megathyrsus maximus (Sin. Panicum maximum) cultivars in the North and Central-West regions of Brazil. In this paper, we report a horse colic outbreak in the Southeast region of Brazil caused by ingestion of the "Colonião" cultivar of M. maximus, which has not previously been considered as toxic. The five affected horses belonged to the Veterinary Platoon based at the Central Ammunition Deposit of the Brazilian Army in the city of Paracambi, Rio de Janeiro state, Brazil. The horses had access to treated water and commercial concentrate, and were located in a field of M. maximus at the time of the outbreak. All horses exhibited clinical signs of colic and bloat, and three of them died. The extend of the clinical course ranged from four to five days in the three animals that died; in the two animals that recovered from the colic episodes, the extend of the clinical courses were 10 and 15 days. Necropsy findings revealed intestinal and gastric bloating and hemorrhages involving the intestinal wall. Light microscopy showed moderate diffuse lymphoplasmacytic and eosinophilic enteritis with multifocal erosions, in addition to submucosal edema associated with multifocal vasculitis. The pathogenesis of colic caused by M. maximus ingestion in horses has not yet been elucidated. Some authors have suggested that higher starch concentrations in M. maximus during the rainy season may be responsible for the toxicity of this plant. However, the findings of this study do not support this hypothesis. As a prophylactic measure, it is suggested that horses do not graze exclusively M. maximus at the beginning of rainy periods, in which regrowth of this grass occurs. In Brazil, outbreaks of horse colic associated with ingestion of varieties of Megathyrsus can also occur outside the North and Midwest regions, under specific climate conditions.
\end{abstract}

INDEX TERMS: Poisonous plants, colic, Panicum maximum, Megathyrsus maximus, cv. Colonião, horses, Brazil.

\footnotetext{
${ }^{1}$ Received on March 20, 2021

Accepted for publication on April 22, 2021.

${ }^{2}$ Setor de Anatomia Patológica Veterinária, Departamento de Epidemiologia e Saúde Pública, Universidade Federal Rural do Rio de Janeiro (UFRRJ), BR-465 Km 7, Seropédica, RJ 23890-000, Brazil. *Corresponding author: ticianafranca19@gmail.com

${ }^{3}$ Pelotão de Veterinária, Exército de Paracambi, Paracambi, RJ, Brazil.

${ }^{4}$ Departamento de Nutrição Animal e Pastagens, Universidade Federal Rural do Rio de Janeiro (UFRRJ), BR-465 Km 7, Seropédica, RJ 23890-000, Brazil.

${ }^{5}$ Graduate Program in Veterinary Medicine, Graduate Program in Veterinary Sciences, Universidade Federal Rural do Rio de Janeiro (UFRRJ), BR-465 Km 7, Seropédica, RJ 23890-000, Brazil.
}

RESUMO.- [Intoxicação por Megathyrsus maximus (Sin. Panicum maximum) cv. Colonião em equinos no estado do Rio de Janeiro.] Surtos de cólica em equinos vêm sendo associados ao pastejo de várias cultivares de Megathyrsus maximus (Sin. Panicum maximum) nas regiões Norte e CentroOeste do Brasil. Neste trabalho relata-se um surto de cólica em equinos determinado pela ingestão da variedade Colonião de M. maximus, cultivar até então não descrita como tóxico. Os cinco equinos, oriundos do Pelotão de Veterinária do Centro de munição do Exército situado no município de Paracambi/ 
RJ, estavam em uma mesma pastagem de $M$. maximus, tinham acesso à água tratada e ao concentrado comercial para equinos. Todos os equinos tiveram sinais clínicos de cólica por timpanismo e três deles morreram. 0 curso clínico variou de quatro a cinco dias nos três equinos que morreram e de 10 a 15 dias nos dois equinos que recuperaram-se da cólica. À necropsia, os principais achados foram timpanismo intestinal e gástrico e hemorragias na parede intestinal. À microscopia havia enterite linfoplasmocítica e eosinofílica difusa moderada com erosões multifocais e edema submucoso associado à vasculite multifocal. A patogênese da cólica pela ingestão de $M$. maximus ainda não foi elucidada, no entanto, alguns autores têm sugerido que uma maior concentração de amido presente na forrageira durante o período de chuvas possa ser responsável pela ação tóxica da planta. Contudo as observações aqui levantadas não dão suporte a essa hipótese. Sugere-se como medida profilática evitar o pastejo exclusivo de M. maximus por cavalos, por meio de pastagens alternativas, principalmente durante o início das chuvas e rebrota da pastagem. Demonstra-se que, no Brasil, os surtos de cólica em equinos associados à ingestão de variedades de Megathyrsus, também podem ocorrer fora das regiões Norte e Centro-Oeste, desde que existam condições climáticas especiais.

TERMO DE INDEXAÇÃO: Plantas tóxicas, cólica, Panicum maximum, Megathyrsus maximus, cv. Colonião, equinos, Brasil.

\section{INTRODUCTION}

Megathyrsus maximus (Sin. Panicum maximum) is native to Africa, and was introduced in Brazil in the 16th century, and recently, plant breeding has provided several cultivars with high productivity such as cv. Tanzania, cv. Massai, and cv. Mombaça (Fonseca \& Martuscello 2010). The modifications caused by massive genetic selection (Peixoto \& Tokarnia 2008) may have resulted in the synthesis of "novel compounds" that may accumulate in the plants, as described for the Australian variety of Urochloa decumbens (Sin. Brachiaria decumbens) and other Urochloa species (Tokarnia et al. 2012). The species $M$. maximus is a common component of cattle diets in Brazil as well as in several other Latin American countries because of its high productivity, good nutritional quality, and easy adaptation. Areas in the Cerrado and Amazon Forest have been used for cultivation of forage plant species, particularly Urochloa spp. and M. maximus, which are used to feed cattle (Furlan et al. 2012). M. maximus is also widely used as forage for horses (Fonseca \& Martuscello 2010), which represent approximately 5.6 million head in Brazil (IBGE 2017).

Some outbreaks of horse colic have been attributed to grazing in areas cultivated with some $M$. maximus cultivars (i.e. Tanzania, Mombaça, and Massai) (Cerqueira et al. 2009). Such outbreaks occurred during periods of rain in the Amazon region, in the states of Pará, Rondônia, and Acre (Cerqueira et al. 2009, Schons et al. 2012, Souza et al. 2017) as well as in the Midwest Region, in Mato Grosso (Dias et al. 2014). This type of horse colic is believed to be associated with the ingestion of this plant in periods of high rainfall and high humidity. However, two outbreaks of equine colic due to the ingestion of $M$. maximus have been described in the Midwest region, in Mato Grosso state during the dry season (Dória et al. 2015).

A clinical picture of horse colic associated with M. maximus was initially described by Cerqueira et al. $(2009,2012)$ in the state of Pará. Modifications introduced by genetic selection in M. maximus are suspected to lead to significant economic losses for ranchers, as they cause fermentative colic in horses and cattle (Embrapa 2009, Riet-Correa et al. 2011, Soares etal. $2014 a, 2014 b)$. In addition, two other clinical conditions have also been associated with the consumption of $M$. maximus by horses: fibrous osteodystrophy - a bone-metabolic disease that leads to a bilateral and symmetrical increase in facial bones due to the prolonged consumption of forages with high levels of oxalate (Tokarnia et al. 2010, 2012) - and angular cheilitis, which is caused by mature, fibrous, and lignified leaves of $M$. maximus that cause mechanical damage to the labial commissure of horses (Barbosa et al. 2009, Tokarnia et al. 2012).

In this paper, we report an outbreak of horse colic caused by the ingestion of $M$. maximus cv. Colonião in the state of Rio de Janeiro (RJ), Brazil.

\section{MATERIALS AND METHODS}

The clinical history and necropsy data were provided by the veterinarian responsible for the horses of the Veterinary Platoon based at the Central Ammunition Deposit of the Brazilian Army in

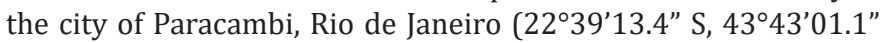
W). Five horses (four males and one female) of unknown breeds between 16 and 21 years of age and weighing between 400 and $450 \mathrm{~kg}$ were kept at this site. The horses were vaccinated, and their anti-parasitic agent administrations were up-to-date. The animals had free access to pasture and treated water, and received concentrate in stalls. Every day, a total of $1 \mathrm{~kg}$ of commercial concentrate was divided in two portions, which were made available at 6 a.m. and 4 p.m. All five horses exhibited clinical signs of colic; three of them died, and were subjected to necropsy. At necropsy, samples of the small intestine, large intestine, liver, kidney, spleen, heart, and lungs were collected, fixed in $10 \%$ buffered formalin, routinely processed for histological examination, and stained with hematoxylin and eosin (HE). Samples of feed and water were sent for chemical analysis by the "Laboratório de Inspeção de Alimentos e Bromatologia" (LIAB - Laboratories of Food Inspection and Bromatology) and to the "Instituto de Biologia do Exército" (IBEX - Institute of Biology of the Brazilian Army). Visits were made to the site after the deaths of the animals, and samples of grass were collected and sent to the Forage and Pasture Sector of the Animal Science Institute of "Universidade Federal Rural do Rio de Janeiro" (UFRRJ) for botanical identification. The forage was identified as M. maximus cv. Colonião. (Fig.1). Small amounts of Paspalum notatum and Sporobulus sp. were also present in the pasture.

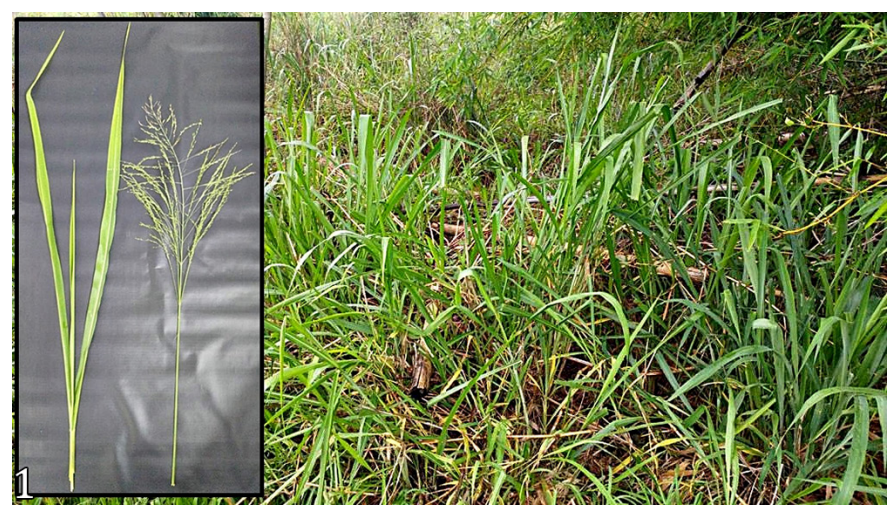

Fig.1. Grass some weeks after outbreak. Inset: Leaves and inflorescence of the Megathyrsus maximus cv. Colonião. 


\section{RESULTS}

According to the veterinarian in charge of the horses, the pasture on which the horses were kept was very dry due to a long period of drought. After intense rain in the first week of August 2017, Megathyrsus maximus began to regrowth. The horses eagerly grazed in the pasture after the rain, and between August 18 and 19, colic symptoms began. The clinical course ranged from four to five days in the three horses that died, and from 10 to 15 days in the two horses that recovered from colic.

All five horses initially exhibited slightly dry and mucuscontaining stools, bloating, and restlessness; they also hit their flanks with the hind limbs, laid and rolled on the floor, and had difficulty to defecate. Additional clinical signs included pale mucous membranes, intestinal hypomotility, and a heart rate of 48-60bpm. Three horses died (one after hitting his head in the stall), and two recovered. All horses received continuous fluid therapy with Ringer's lactate solution and slow intravenous administration of a product containing calcium borogluconate in the two days following the onset of colic, in order to stimulate intestinal motility.
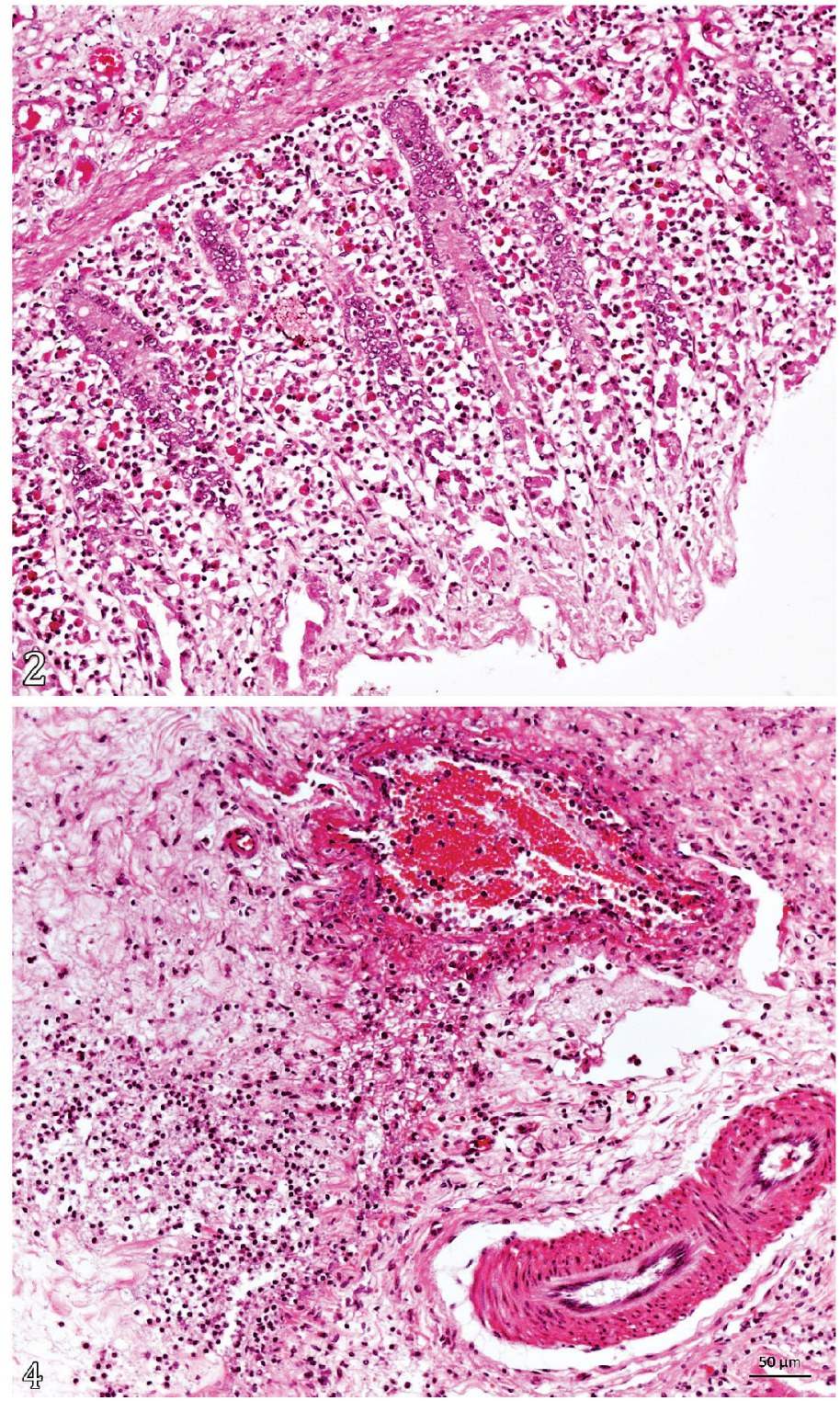

At necropsy, excessive amounts of gas were observed in the stomach, cecum, large colon, and small colon of the three horses. The stomach and small intestine were filled with a foul-smelling greenish fluid, and their mucosas were congested. The contents of the colon were moderately dry, and some areas of the colon wall were dark red. There were multifocal suffusions in the serosa of the small and large intestines. Pulmonary, splenic, and renal congestion was also observed. Histopathological examination revealed lesions in the large and small intestines, which were more pronounced in the latter. The alterations observed were associated with multifocal loss of the superficial epithelial lining, with inflammatory infiltrates in the lamina propria composed of moderate numbers of plasma cells, lymphocytes, and eosinophils; at times, mild edema was present (Fig.2). In the submucosa, there was moderate diffuse edema with multifocal areas of vasculitis with fibrinous effusion and adjacent inflammatory infiltrates consisting mainly of histiocytes and eosinophils (Figs.3 and 4). There were also discrete multifocal hemorrhagic areas in the submucosa and serosa. In the liver, there was moderate diffuse hepatocellular swelling and random hepatocytes with

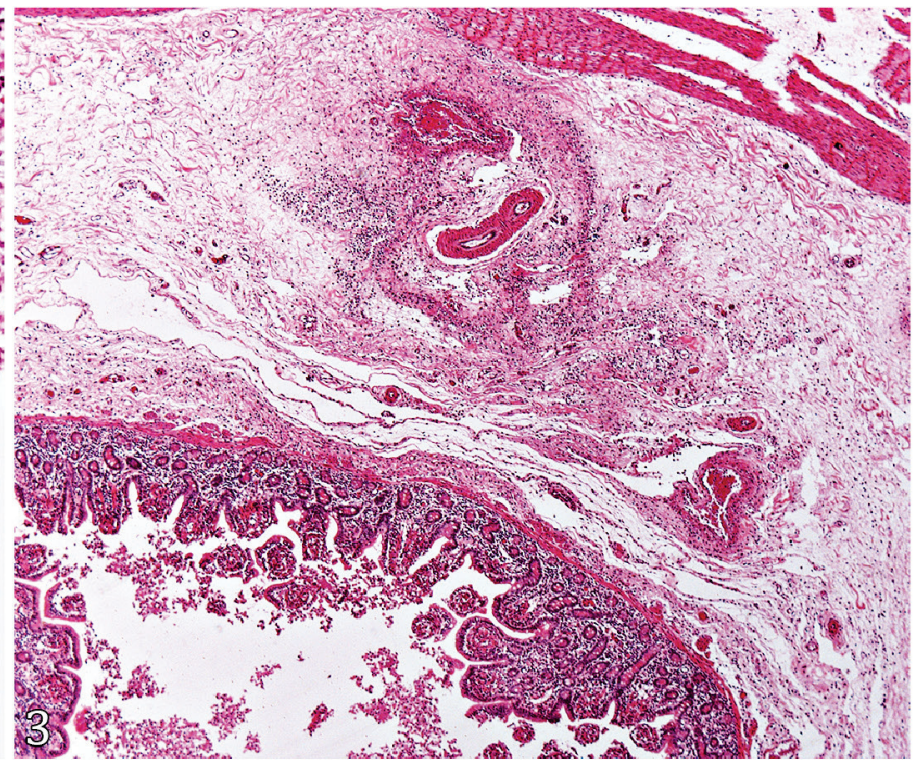

Fig.2-4. Poisoning by Megathyrsus maximus (Sin. Panicum maximum) cv. Colonião in horses in the state of Rio de Janeiro. (2) Small intestine. Lamina propria with moderate inflammatory infiltrate composed of plasmocytes, lymphocytes and eosinophils. There is complete stripping of the superficial epithelial lining. HE, obj.20x. (3) Small intestine. Moderate submucosal edema and perivascular inflammatory infiltrate associated with vasculitis. HE, obj.5x. (4) Small intestine. Vasculitis and adjacent inflammation, mainly composed of histiocytes and eosinophils, and edema with fibrinous effusion. HE, obj.20x. 
hypereosinophilic cytoplasm and pycnotic nuclei, in addition to moderate diffuse congestion. Eosinophilic globular material (compatible with shock corpuscles) was observed in the sinusoids and hepatic veins. The other organs evaluated had moderate diffuse congestion.

The concentrate and water samples analyzed were consistent with normal standards.

\section{DISCUSSION}

The morphological diagnosis was moderate diffuse lymphoplasmacytic and eosinophilic enteritis with multifocal erosions and moderate to severe diffuse submucosal edema associated with multifocal vasculitis and fibrinous effusion and mild multifocal hemorrhage. These lesions, which are similar to those described in the fatal outbreaks of horse colic due to the ingestion of other Megathyrsus maximus cultivars (Cerqueira et al. 2009, Schons et al. 2012, Dória et al. 2015, Souza et al. 2017), together with a history of ingestion of new sprounting of $M$. maximus after intense rain and the clinical signs of colic, allowed the establishment of a diagnosis of poisoning by this grass.

The low availability of forage during the dry season and the rapid regrowth of $M$. maximus after rains were interpreted as factors that favored the avid intake of this forage grass by the horses. The month of August is usually dry in the Southeast region, and the average rainfall is generally low; however, the beginning of August 2017 was atypical in the Paracambi region. Outbreaks of horse colic caused by $M$. maximus in the state of Rondônia occurred during the rainy season, when pastures were in the regrowth phase (Souza et al. 2017). On the other hand, other authors reported that outbreaks of horse colic associated with the ingestion of M. maximus in the state of Mato Grosso occurred during a period of drought (Dória et al. 2015); those authors did not determine if, in spite of the drought, it rained in the days that preceded the cases of horse colic in their study.

Outbreaks of acute intestinal bloating in horses and mules kept in pastures containing M. maximus cv. Tanzania, cv. Massai and cv. Mombaça have been reported in the North (Cerqueira et al. 2009, 2012, Souza et al. 2017) and Central-West (Dória et al. 2015) regions of Brazil. In the cases reported in Rondônia state, the morbidity was $31.6 \%$, and the lethality was $86.1 \%$ (Souza et al. 2017). In the cases reported in the state of Pará, the morbidity was 34\%, and the lethality was 36.5\% (Cerqueira et al. 2009). In this study, morbidity and lethality were $100 \%$ and $60 \%$, respectively. In the colic outbreak described here, the time from the onset of clinical signs until death ranged from four to five days, which was longer than that observed by Cerqueira et al. (2009), which ranged from 12 to four days, and Souza et al. (2017), from six to 48 hours.

The clinical signs (Cerqueira et al. 2012), macro and microscopic alterations found in this study did not differ substantially from those described previously by other authors (Cerqueira et al. 2009, Dias et al. 2014, Dória et al. 2015).

The cause of colic due to the ingestion of varieties of M. maximus has not yet been clarified; however, some possible etiologies have already been suggested, including overload by highly fermentable carbohydrates and high oxalate content (Cerqueira et al. 2009, Souza et al. 2017). It is postulated that non-structural carbohydrates (NSCs) are synthesized by grass during the regrowth phase (which occurs in the rainy season) and are readily fermented by equine gut microbiota, causing colic. The levels of NSC in M. maximus found in experiments carried out on horses were almost double the value of the average values found in the same forage grass in Brazil, which suggests that colic caused by M. maximus in the Amazon region could be linked to high concentrations of rapidly fermentable carbohydrates in the large intestine (Cerqueira 2010). Souza et al. (2017) also suggested that the cause of colic in horses kept in pastures containing regrown $M$. maximus could be the high starch content of this resprouting grass. In that study, chemical analyses of $M$. maximus specimens harvested from areas where colic cases occurred exhibited starch levels between $8.3 \%$ and $9.2 \%$. However, if we consider that a 400 kg horse consumes $2 \%$ of its body weight in dry matter from a $\mathrm{C}_{4}$ forage with $10 \%$ starch (which is a quite high content, and thus unlikely to occur naturally in $\mathrm{C}_{4}$ grasses), the daily starch intake would be $400 \mathrm{~kg} \times 0.02 \times 0.1=0.8 \mathrm{~kg}$ of starch per day. Therefore, this value is below the lowest recommendation proposed by Hoffman et al. (2001). In horses that graze for 12 hours a day, the starch intake will be $66.7 \mathrm{~g}$ per hour, a rate that is extremely safe to avoid colic caused by starch. On the other hand, horses do not tolerate or digest foods whose starch is formed predominantly by amylopectin, such as corn starch. Although there has been no analysis of the structural composition of starch in our forage, these levels are naturally low when compared to corn or sorghum. Therefore, the hypothesis that the high starch content of $M$. maximus (as well as other $\mathrm{C}_{4}$ forage grasses) alone is responsible for fermentative colic has little support.

Additionally, even if we added $0.8 \mathrm{~kg}$ of starch, supposedly contained in the pasture, to the daily total starch content present in the concentrate ingested by horses in the present outbreak ( $1 \mathrm{~kg}$ of a typical adult horse concentrate containing $50 \%$ starch $=0.50 \mathrm{~kg}$ of starch/day), the total starch intake would be around $1.30 \mathrm{~kg}$ per day, which would still be safe. The critical limit for starch overload in Equidae is estimated to be $0.2 \%-0.4 \%$ of body weight at each meal (Hoffman et al. 2001, Kienzle et al. 2002). Therefore, a $400 \mathrm{~kg}$ horse receiving two meals per day would eat between $1.6(400 \mathrm{~kg} \times 0.002 \times$ 2 ) and $3.2(400 \mathrm{~kg} \times 0.004 \times 2) \mathrm{kg}$ of starch per day; such an amount of starch would be contained in approximately 3 to $6 \mathrm{~kg}$ of a standard equine concentrate. From these estimates, the hypothesis that ingestion of starch present in tropical grasses causes horse colic loses much of its relevance.

It seems unlikely that high oxalate content is the cause of colic caused by M. maximus. Similar to Cerqueira et al. (2009), we also found no signs of nutritional hyperparathyroidism (fibrous osteodystrophy) in the horses evaluated.

Horses are predisposed to intestinal bloating owing to the anatomical features of their gastrointestinal tract (Pessoa et al. 2012). Factors such as changes in management and diet, physical activity, parasitic infestations, displacement of the colon, and compaction are common causes of intestinal bloating and colic (Plummer 2009). In the present study, there were no phytobezoars, foreign bodies, displacements of the colon, cecal volvulus, abdominal hernias, or significant infestations by nematodes that could cause intestinal bloating and/or colic in the horses. In addition, there were no sudden changes in the diet if the animals, and the amount of concentrate offered to them was low and insufficient to cause colic in adult horses ( $1 \mathrm{~kg}$ of concentrate divided in two 500-g meals 
per day). A clinical picture similar to that caused by poisoning by M. maximus has been described in horses that consumed cantharidin, a toxin found in beetles (Epicauta spp.). That toxin contaminates hay or pastures, mainly alfalfa (Cheeke 1998). However, the horses involved in this outbreak did not eat alfalfa hay or graze in a pasture infested by these insects, and they did not exhibit alterations in the urinary tract as those that occurred in cases of poisoning by cantharidin.

In the two outbreaks reported in the city of Cuiabá, Mato Grosso state, it should be noted that 22 horses were affected. Of these, 15 recovered after intensive clinical treatment (analgesics, antiphysetics, and fluid therapy) and two after surgical treatment (laparotomy) (Dória et al. 2015). In the present study, after receiving treatment, two animals recovered from M. maximus poisoning. The clinical presentation of tympanic colic observed in this study is difficult to approach clinically/surgically owing to its acute nature. Actions to avoid this problem on farms must be based mainly on prophylaxis, which includes keeping horses from grazing in pastures rich in M. maximus especially during its regrowth phase, which takes place after rains. In horse breeding farms, areas with alternative pasture grasses, such as Cynodon spp., should be implemented, and horses must be relocated to these fields during after rains (Cerqueira et al. 2009, Embrapa 2009, Tokarnia et al. 2012).

\section{CONCLUSIONS}

Horse colic can also occur in the Southeast region owing to bloating in horses recently introduced into pastures during the regrowth phase of Megathyrsus maximus, even in a dry season.

An outbreak of horse colic caused by the cultivar Colonião of M. maximus has not yet been described in Brazil.

Conflict of interest statement.- The authors declare no conflicts of interest. The authors are solely responsible for the content of this study.

\section{REFERENCES}

Barbosa J.D., Albernaz T.T., Riet-Correa G., Cerqueira V.D., Soares S.O., Campos K.F., Oliveira C.M.C. \& Duarte M.D. 2009. Queilite angular traumática em equinos associada à ingestão de Panicum maximum. Pesq. Vet. Bras. 29(5):428-430.<https://dx.doi.org/10.1590/S0100-736X2009000500012>

Cerqueira V.D. 2010. Cólica em equídeos mantidos em diferentes cultivares de Panicum maximum no bioma amazônico. Doctoral Dissertation in Sciences, Faculdade de Medicina Veterinária e Zootecnia, Universidade de São Paulo, São Paulo. 90p.

Cerqueira V.D., Riet-Correa G., Barbosa J.D., Duarte M.D., Oliveira C.M., Oliveira C.A., Tokarnia C., Lee S.T. \& Riet-Correa F. 2009. Colic caused by Panicum maximum toxicosis in equidae in northern Brazil. J. Vet. Diagn. Invest. 21(6):882-888. <https://dx.doi.org/10.1177/104063870902100622> <PMid:19901296>

Cerqueira V.D., Riet-Correa G., Duarte M.D., Oliveira C.A. \& Riet-Correa F. 2012. Bloat and colic in horses experimentally induced by the ingestion of Panicum maximum cv. Mombaça. Ciência Rural 42(11):2030-2033. <https://dx.doi.org/10.1590/S0103-84782012001100019>

Cheeke P.R. 1998. Natural Toxicants in Feeds, Forages, and Poisonous Plants. 2nd ed. Interstate Publishers, Danville. 479p.

Dias G.B.G., Falcão C.M., Arruda F.P., Ducatti K.R., Cardoso K.G.M., Colodel E.M., Santos C.E.P. \& Antoniassi N.A.B. 2014. Surto de cólica por consumo de Panicum maximum (cv. Massai) em equinos no município de Poconé, Mato Grosso, Brasil. Anais do VII Encontro Nacional de Diagnóstico Veterinário, Porto Alegre, RS. (Resumo)
Dória R.G.S., Freitas S.H., Laskoski L.M., Carvalho M.B., Monteiro A.O.N., Camplesi A.C. \& Valadão C.A.A. 2015. Avaliação clínica e da evolução dos casos de cólica associados ao Panicum maximum no estado de Mato Grosso, Brasil. Revta Bras. Med. Vet. 37(4):303-308.

Embrapa 2009. Cólica em equídeos sob pastejo em Panicum maximum na região Amazônica. Nota Técnica, Embrapa Gado de Corte, Campo Grande, MS.

Fonseca D.M. \& Martuscello J.A. 2010. Plantas Forrageiras. Editora da Universidade Federal de Viçosa, Viçosa. 537p.

Furlan F.H., Colodel E.M., Lemos R.A.A., Castro M.B., Mendonça F.S. \& RietCorrea F. 2012. Poisonous plants affecting cattle in central-western Brazil. Int. J. Poisonous Plant Res. 2:1-13.

Hoffman R.M., Wilson J.A., Kronfeld D.S., Cooper W.L., Lawrence L.A., Sklan D. \& Harris P.A. 2001. Hydrolyzable carbohydrates in pasture, hay, and horse feeds: direct assay and seasonal variation. J. Anim. Sci. 79(2):500506. <https://dx.doi.org/10.2527/2001.792500x> <PMid:11219461>

IBGE 2017. Tabela 3939 - Efetivo dos rebanhos, por tipo de rebanho. Instituto Brasileiro de Geografia e Estatística, Rio de Janeiro. Available at <https:// sidra.ibge.gov.br/tabela/3939\#resultado> Accessed on Feb. 18, 2019.

Kienzle E., Fehrle S. \& Opitz B. 2002. Interactions between the apparent energy and nutrient digestibilities of a concentrate mixture and roughages in horses. J. Nutr. 132(6Supl.2):1778S-1780S. <https://dx.doi.org/10.1093/ jn/132.6.1778S > <PMid:12042526>

Peixoto \& Tokarnia 2008. Personal communication. Graduate Program in Veterinary Medicine, Universidade Federal Rural do Rio de Janeiro (UFRRJ), Seropédica, RJ.

Pessoa A.F.A., Miranda Neto E.G., Pessoa C.R.M., Simões S.V.D., Azevedo S.S. \& Riet-Correa F. 2012. Abdômen agudo em equídeos no semiárido do Nordeste do Brasil. Pesq. Vet. Bras. 32(6):503-509. <https://dx.doi.org/10.1590/ S0100-736X2012000600006>

Plummer A.E. 2009. Impactions of the small and large intestines. Vet. Clin. N. Am., Equine Pract. 25(2):317-327. <https://dx.doi.org/10.1016/j. cveq.2009.04.002 > <PMid:19580942>

Riet-Correa B., Riet-Correa F., Simões S.V. \& Silva T.D. 2011. Alterações digestivas em bovinos mantidos em pastagem de Panicum maximum cultivar Tanzânia. Vet. Zootec. 18(3):633-635.

Schons S.V., Lopes T.V., Melo T.L., Lima J.P., Riet-Correa F., Barros M.A.B. \& Schild A.L.P. 2012. Intoxicações por plantas em ruminantes e equídeos na região central de Rondônia. Ciência Rural 42(7):1257-1263. <https:// dx.doi.org/10.1590/S0103-84782012005000047>

Soares F.J., Reinicke F., Pereira H.S., Fink A.A.B., Scherer F., Melo T.L., Rodrigues E.H.S., Ferreira E., Riet-Correa F. \& Schons S.V. 2014a. Intoxicação experimental por Panicum maximum cv. Mombaça em bovinos. Anais VIII Encontro Nacional de Diagnóstico Veterinário, Cuiabá, MT. (Resumo)

Soares FJ., Reinicke F., Pereira H.S., Fink A.A.B., Scherer F., Melo T.L., Rodrigues E.H.S., Ferreira E., Riet-Correa F. \& Schons S.V. 2014b. Distensão cecal em bovinos em sistema de pastejo intermitente com Panicum maximum cv. Tanzania e cv. Mombaça. Anais VIII Encontro Nacional de Diagnóstico Veterinário, Cuiabá, MT. (Resumo)

Souza T.M., Lopes T.V., Wajnsztejn H., Pazdiora R.D., Riet-Correa F., Fujihara R.I., Mansur I.M. \& Schons S.V. 2017. Timpanismo gastrointestinal em equídeos alimentados com Panicum maximum com alto conteúdo de amido. Pesq. Vet. Bras. 37(10):1079-1084. <https://dx.doi.org/10.1590/ S0100-736X2017001000007>

Tokarnia C.H., Peixoto P.V., Barbosa J.D., Brito M.F. \& Döbereiner J.2010. Deficiências Minerais em Animais de Produção. Helianthus, Rio de Janeiro, p.191.

Tokarnia C.H., Peixoto P.V., Barbosa J.D., Brito M.F. \& Döbereiner J. 2012. Plantas Tóxicas do Brasil para Animais de Produção. $2^{\text {a }}$ ed. Helianthus, Rio de Janeiro, p.586. 